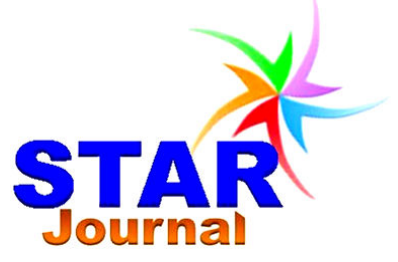

ISSN: 2226-7522(Print) and 2305-3327 (Online) Science, Technology and Arts Research Journal April-June 2013, 2(2): 70-74 www.starjournal.org Copyright@2013 STAR Journal. All Rights Reserved

Original Research

\title{
Phytoplankton Community Composition in Gowrikere Tank, Anandapura, Sagara, Shivamogga, Karnataka, India
}

\author{
Vasantha Naik $\mathrm{T}^{1 *}$, Puttaiah $\mathrm{ET}^{2}$, Ravikumar Patil $\mathrm{HS}^{3}$, Sayeswara $\mathrm{HA}^{4}$ and Nafeesa Begum ${ }^{5}$ \\ ${ }^{1}$ Department of Botany, DRM Science College, Davangere University, Davangere-577066, Karnataka, India \\ ${ }^{2}$ Gulbarga University, Gulbarga, Karnataka, India \\ ${ }^{3}$ Department of Biotechnology, G.M. Institute of Technology, Davangere-577066, Karnataka, India \\ ${ }^{4}$ Department of Zoology, Sahyadri Science College, Kuvempu University, Shivamogga, Karnataka, India \\ ${ }^{5}$ Department of Botany, Sahyadri Science College, Kuvempu University, Shivamogga, Karnataka, India
}

\begin{tabular}{|c|c|}
\hline \multirow{4}{*}{ 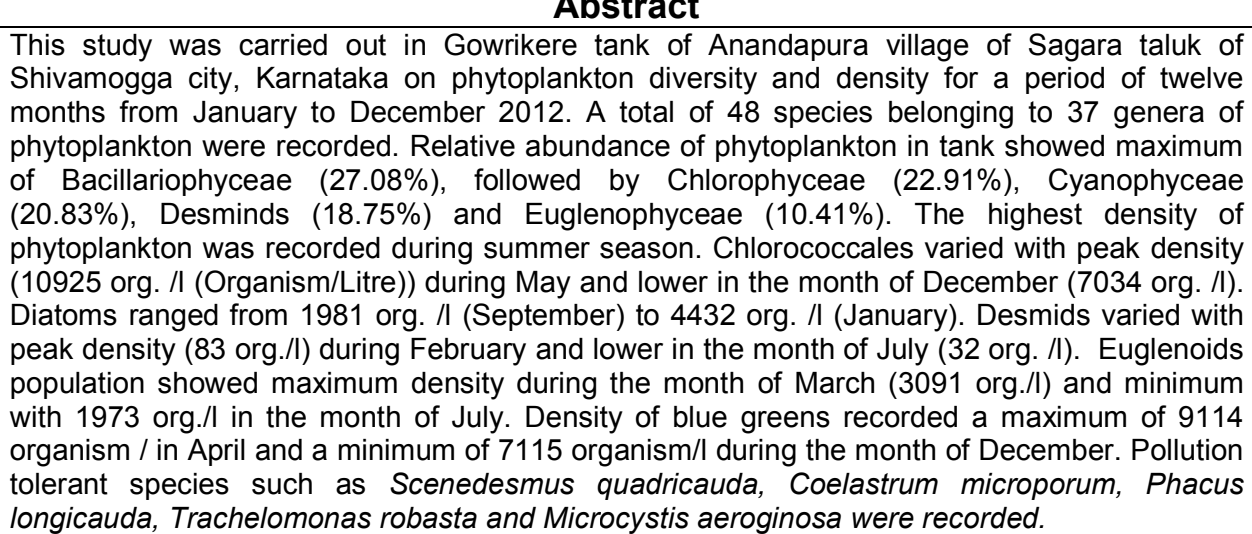 } & Article Info \\
\hline & $\begin{array}{l}13 \\
013 \\
13\end{array}$ \\
\hline & s \\
\hline & \\
\hline
\end{tabular}

\section{INTRODUCTION}

Phytoplanktons are photosynthesizing microscopic organisms that inhabit the upper sunlit layer of almost all oceans and bodies of freshwater. They form bulk of food for zooplankton, fishes and other aquatic organisms. Phytoplankton constitute the primary level of the aquatic food chain by converting solar radiant energy into biomass through photosynthesis. Therefore, they act as primary produces and represent themselves as a direct food source for the aquatic animals. They also play an important role in conditioning the microclimate by regulating the level of dissolved oxygen, a vital gas for aquatic life (Sudhakara et al., 2012). The community composition of phytoplankton is largely influenced by the interaction of a number of physico-chemical factors (Shinde et al., 2012). Plankton of pond ecosystems was studied by several investigators (Kumar and Dutta, 1991; Bhat, et al., 1991; Sayeswara et al., 2011; Sayeswara et al., 2012). Phytoplankton study provides a relevant and convenient point of focus for research on the mechanism of eutrophication and is adverse impact on the aquatic ecosystem. The planktonic study is a very useful tool for the assessment of water quality in any type of water body and also contributes to understanding of the basic nature and general economy of the lake (Pawar et al., 2006). The maintenance of healthy aquatic ecosystem is dependent on the abiotic properties of water and the biological diversity of the ecosystem. In view of the importance of the study of phytoplankton, the present study was undertaken to assess biodiversity and density of phytoplankton in Gowrikere tank of Anandapura village, Shivamogga. 
Vasantha Naik et al.,

\section{MATERIALS AND METHODS}

\section{Study Area}

Gowrikere tank (Anandapura village) is a perennial freshwater body situated at about $16 \mathrm{~km}$ away from the Sagara town, located between $14^{\circ} 4^{\prime}$ $\mathrm{N}$ latitude and $75^{\circ} 38^{\prime} \mathrm{E}$ longitude. This is medium sized tank, with total water spread of 27.79 hectare, where rain is the main source of water. The river basin of the tank is Krishna. The water has undergone moderate changes in the physicochemical properties due to overflowing of water from adjacent paddy fields and other excessive human activities. The water is used for agricultural purpose and domestic activities.

\section{Plankton Analysis}

For analysis of plankton, one liter of composite water samples at surface level was collected at interval of 30 days from January to December 2012. One liter of sample was fixed with $20 \mathrm{ml}$ of $1 \%$ Lugol's iodine solution and kept 24 hours for sedimentation. $100 \mathrm{ml}$ of sample is subjected to centrifugation at $1500 \mathrm{rpm}$ for 20 minutes and used for further investigation. The filtered plankton were collected in separate bottles and preserved using $10 \%$ formalin. Identification of plankton up to species level was done by referring standard manuals (Frich, 1945; Deshikachary, 1959; Needham and Needham, 1962; Philipose, 1967). Quantitative estimation of phytoplankton was done using by a Sedgewick Rafter counting cell.

\section{RESULTS AND DISCUSSION}

A total of 48 species belonging to 37 genera of phytoplankton were recorded (Table 1). Monthly occurrence of different groups of phytoplankton density is given in table 2. Genus compositions of different groups are shown in Figures 1-5. Kumawat and Jawale (2003) recorded 50 species of phytoplankton from a fish pond at Anjale, Maharashtra. Nafeesa Begum et al. (2011) recorded 56 species of phytoplankton from a Bethur pond near Davangere, Karnataka. Diatoms represent the first dominated group among the phytoplankton. The Gowrikere tank comprises of 12 genera and 13 species of diatoms. The genus Gomphonema was represented by 2 species and other genera like Cymbella, Fragillaria, Gyrosigma, Melosira, Navicula, Pinnularia, Surirella, Synandra, Tabullaria and Amphora were represented by single species each. Abundance ranges from minimum of $32 \mathrm{org} . / \mathrm{I}$ in July to a maximum of $81 \mathrm{org} . / / \mathrm{in}$ February. Some of the pollution tolerant diatoms (Palmer, 1969) were recorded from the study area are Navicula sp., Cymbella tumida and Pinnularia sp.
Sci. Technol. Arts Res. J., April-June 2013, 2(2): 70-74

Table 1: List of Phytoplankton in Gowrikere tank.

\section{Chlorophyceae}

Ankistrodesmus falcatus, Ankistrodesmus spiralis, Coelastrum microporum, Dimorphococcus sp., Eudorina elegans, Pediastrum duples, Pediastrum simplx, Scendesmus quaricauda, Scendesmus dimorphos, Selanastrum gracile, Selanastrum westii.

\section{Bacillariophyceae}

Amphora sp., Cymbella tumida, Fragillaria capucina, Gomphonema lanceolatum Gomphonema abbreviatum, Gyrosira acuminatum, Melosira granulate, Navicula sp., Nitzchia amphibian, Pinnularia gibba, Surirella sp., Synandra tabulate, Tabularia flocculosa.

\section{Cynophyceae}

Merismopedia glauca, Merismopedia tenuissima, Merismopedia elegans, Microcystis aeroginosa, Nostoc muscorm, Oscillatoria Formosa, Phormidium sp., Rivuleria sp., Spirulina major, Synechocystis sp.

\section{Desmids}

Closterium sp., Cosmarium depressum, Cosmarium punetulatum, Cosmarium granulatum, Cosmarium constractum, Euastrum sublobatum, Micrasteria sp., Staurastrum gracile, Staurastrum sp.

\section{Euglenophyceae}

Euglena sp., Phacus longicauda, Phacus undulate, Trachelomonas robasta, Strombomonas gibberosa.

Gowrikere tank recorded 7 genera and 11 species of Chlorococcales. The genera Ankistrodesmus, Pediastrum, Scendesmus and Selanastrum were represented by two species each and other genera like Coeleastrum, Dimorphococcus and Eudorina were represented by single species. The population density of Chlorococcales reached its peak in May with 10925 org./l, while in December it was least with 7034 org./l. Some of the pollution tolerant species (Palmer, 1969) identified were Scendesmus quadricauda and Coelastrum sp.

The tank recorded 5 genera and 9 species of desmids. The genus Cosmarium was represented by 4 species, Staurastrum by 2 species and other genera like Euastrum, Micrasteria, and Closterium by a single species. Density of desmids was maximum of 83 org.// in February and a minimum of 32 org./l during July. 
Table 2: Monthly occurrence of different groups of phytoplankton density in Gowrikere tank.

\begin{tabular}{lccccc}
\hline $\begin{array}{c}\text { Month } \\
\text { and year }\end{array}$ & Chlorophyceae & Bacillariophyceae & Desmids & Euglenoids & Cyanophyceae \\
\hline January 2012 & 9435 & 4432 & 45 & 2176 & 8615 \\
February 2012 & 9860 & 3921 & 83 & 2288 & 7623 \\
March 2012 & 8114 & 3620 & 81 & 3091 & 9114 \\
April 2012 & 10115 & 4203 & 69 & 1986 & 8633 \\
May 2012 & 10925 & 3822 & 71 & 2493 & 8718 \\
June 2012 & 8626 & 2924 & 49 & 2376 & 7922 \\
July 2012 & 8121 & 2415 & 32 & 1973 & 8015 \\
August 2012 & 8626 & 2237 & 36 & 2181 & 7639 \\
September 2012 & 7620 & 1981 & 47 & 2680 & 1893 \\
October 2012 & 7251 & 2114 & 58 & 2576 & 8115 \\
November 2012 & 7630 & 2214 & 49 & 2171 & 7314 \\
December 2012 & 7034 & 2158 & 59 & 2169 & 7115 \\
\hline
\end{tabular}

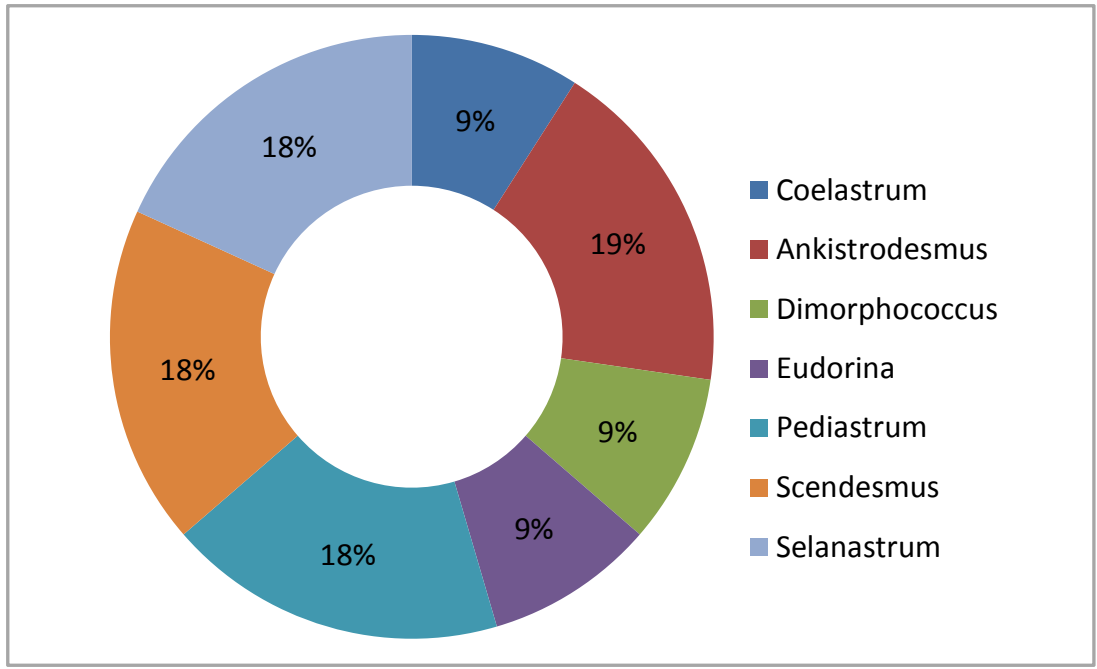

Figure 1: Genus composition of Chlorophyceae.

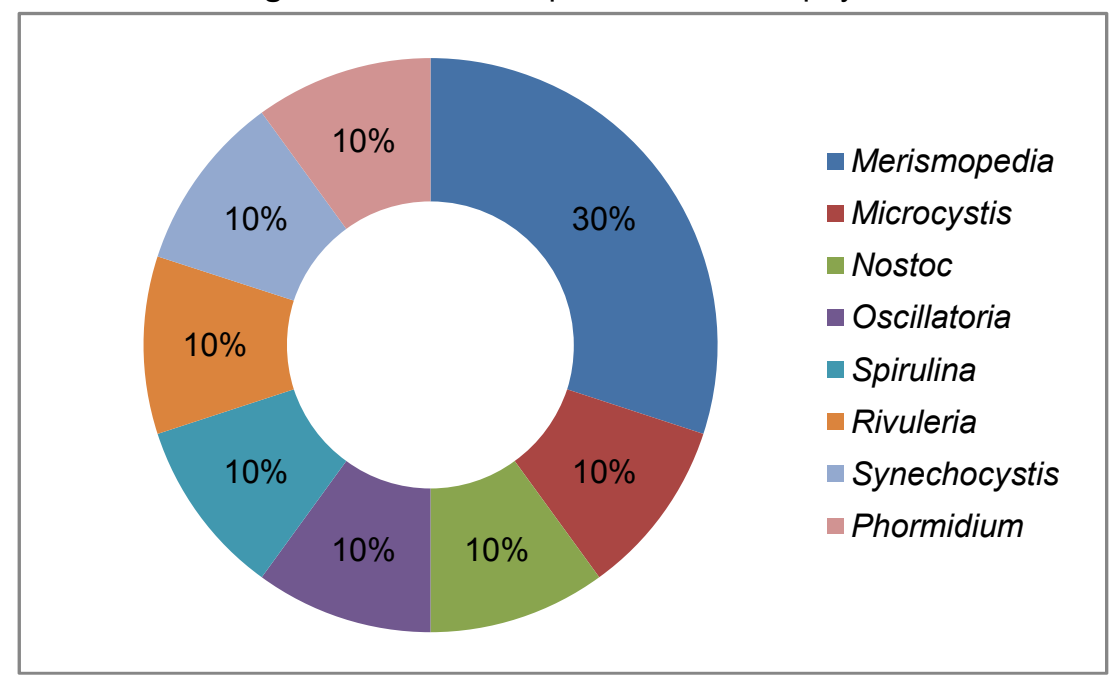

Figure 2: Genus composition of Cyanophyceae. 


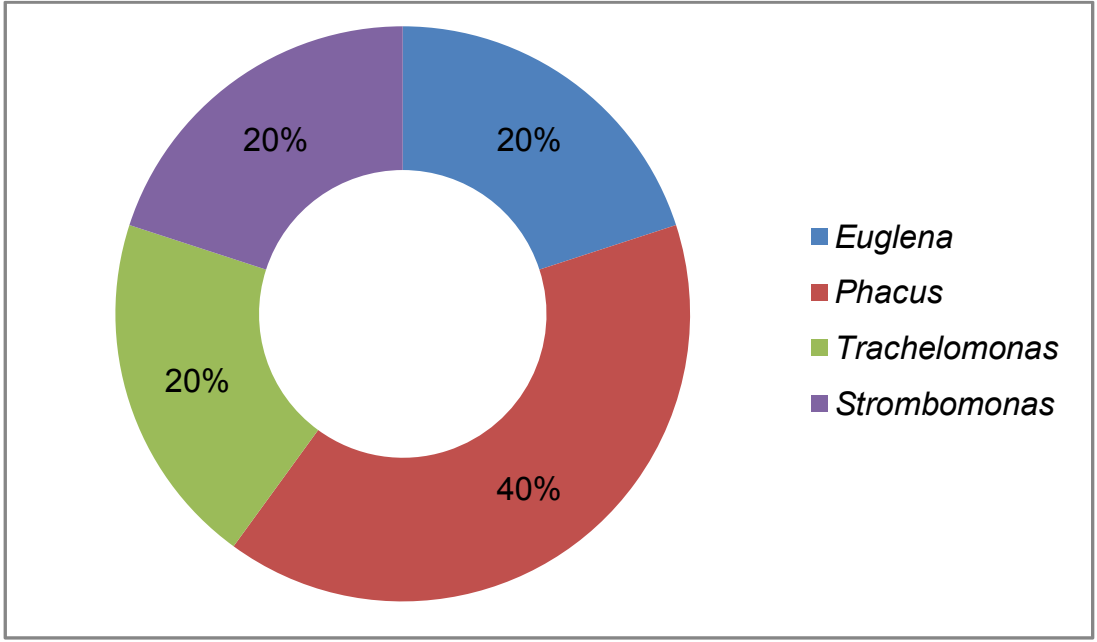

Figure 3: Genus composition of Euglenophyceae.

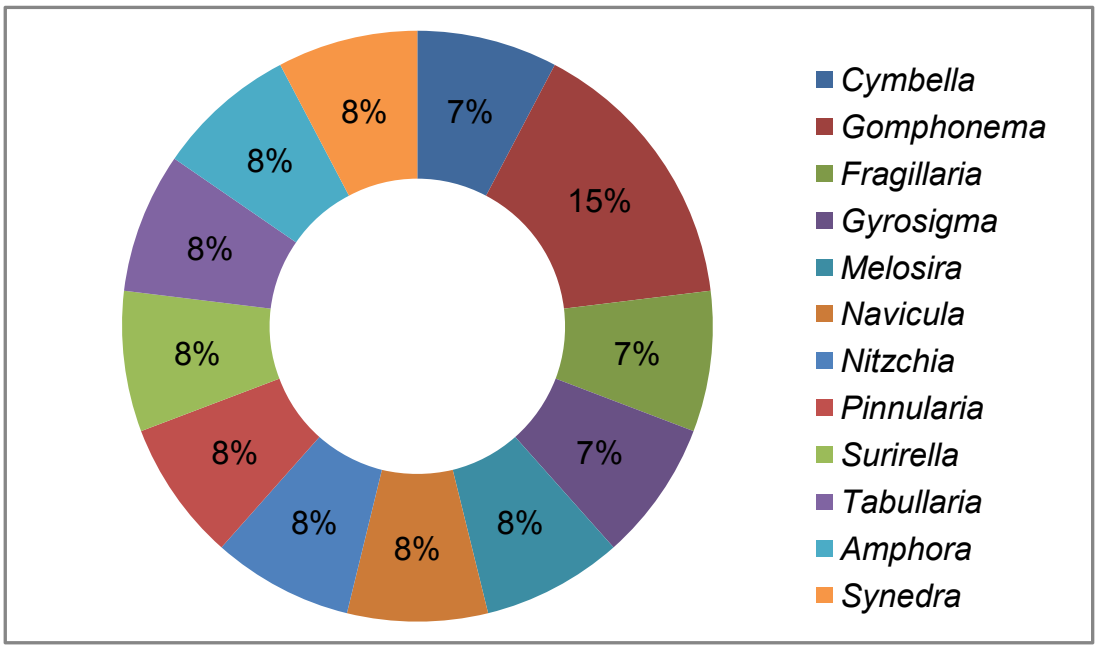

Figure 4: Genus composition of Bacillariophyceae.

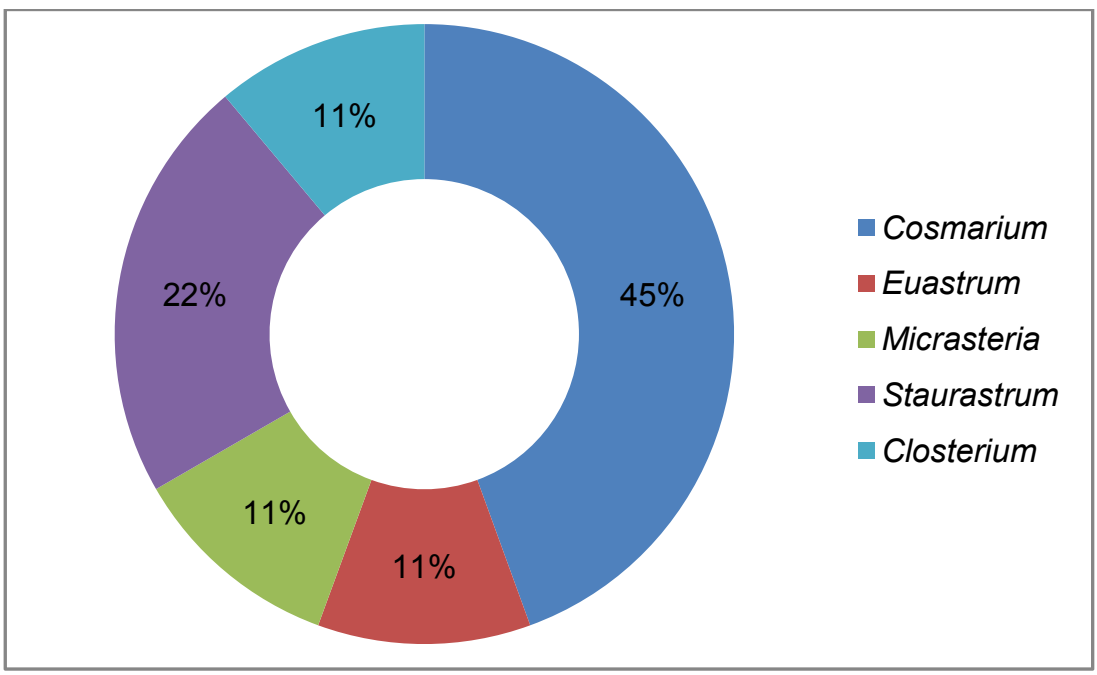

Figure 5: Genus composition of Desmids. 
Vasantha Naik et al.,

Blue greens represented by 8 genera and 10 species. If the diversity of blue greens is considered, the genus Merismopedia was represented by 3 species and other genera like Nostoc, Oscillaria, Spirulina, Rivuleria, Synechocystis and Phormidium each by a single species. Density of blue greens recorded a maximum of 9114 org./I in March and a minimum of 7115 org./l in December. Some of the pollution tolerant species recorded from the study area are Microcystis aeroginosa and Oscillatoria formosa. Microcystis aeroginosa is used as the best indicator of pollution and is associated with highest degree of civic pollution. In the present study Micricystis aeroginosa was recorded.

Comparatively euglenoid population was less which represents 4 genera and 5 species. Phacus were represented by 2 species, Euglena, Trachelomonas and Strombomonas by a single species each. The population density of euglenoids reached its peak in March with 3091 org./l, while in July it was least with 1973 org./l. Some of the pollution tolerant euglenoid (Palmer, 1969) recorded were Euglena sp., Phacus sp. and Trachelomonas sp. whose density was in Gowrikere tank which indicated the presence of organic matter in the water body.

\section{CONCLUTION}

The water samples from Gowrikere tank was collected and analyzed for plankton composition. The ecological status of the tank was found to be impoverished in terms of species composition. A rich phytoplankton flora with 13 species of diatoms, 11 species of chlorococcales, 10 species of blue greens, 9 species of desmids and 5 species of euglenoids were reported. The presence of euglenophycean members indicate that the water is organically polluted as euglenoids are the bioindicators of pollution.

\section{ACKNOWLEDGEMENTS}

The authors express their gratitude to Prof. N. Srinivasa, Principal, D.R.M Science College, Davangere and Dr. Gayathri Devi Sajjan, Principal, Sahyadri Science College, Shivamogga for providing facilities and encouragement.
Sci. Technol. Arts Res. J., April-June 2013, 2(2): 70-74

\section{REFERENCES}

Bhat, L.R., Lacoul, P., Lekhak, H.D., Jha, P.K. (1991). Physico-chemical characteristics \& phytoplanktontons of Taudaha Lake, Katmandu. Pollution Research 18(4): 353-358.

Deshikachary, T.V. (1959). Cyanophyta. ICMR, New Delhi.

Frich, F.E. (1945). The structure and reproduction of Algae. Volume 2. Cambridge University Press, London, UK.

Kumar, S., Datta, S.P.S. (1991). Studies on Phytoplanktonic population dynamics in Kunjwani pond, Jammu. Hydobiologia 7: 55-59.

Kumawat, D.A., Jawale, A.K. (2003). Phytoplankton of a fish pond at Anjale, Maharashtra. Ecology Environment and Conservation 9(1): 411-415.

Nafeesa Begum, Sayeswara, H.A., Naik, K.L. (2011). Seasonal variations of Phytoplankton diversity in Bethur pond near Davangere, Karnataka, Environment and Ecology. 29(3A): 1355-1359.

Needham, J.G., Needham, P.R. (1962). A Guide to study of freshwater biology. Holden Bay. San Francisco, U.S.A.

Palmer, C.M. (1969). A composite rating of algae tolerating organic pollution. Journal of Phycology 5: 76-82.

Pawar, S.K., Pulle, J.S., Shende, K.M. (2006). The study of phytoplankton of pethwadaj Dam, Taluka kandhar, Nanded, Maharashtra. Journal Aquatic Biology 21:1-6.

Philipose, M.T. (1967). Chlorocaccales: Monographs on algae. ICAR Publ. New Delhi.

Sayeswara, H.A., Mahesh Anand Goudar, Manjunatha, R. (2011). Water quality evaluation and phytoplankton diversity of Hosahalli pond, Shivamogga, Karnataka (India). International Journal of Chemical Sciences 9(2): 805-812.

Sayeswara, H.A., Mahesh Anand Goudar, Nafeesa Begum. (2012). Physico-chemical profile and phytoplankton diversity of Murughamatta tank, Shivamogga, Karnataka, India. Pollution Research 31(3): 351-356.

Shinde, S.E., Patthan, T.S., Sonawane, D.L. (2012). Seasonal variations and biodiversity of phytoolankton in Harsool-savangi dam, Aurangabad, India. Journal of Environment Biology 33: 643-647.

Sudhakar, O., Neela Rani, P., Venugopal, G., George, J.P. (2012). Seasonal variations of phytoplankton population in Powai lake, Mumbai, India. Ecology, Environment \& Conservation 18(4): 993-996. 